\title{
Development and Characterization of Gossypium hirsutum and Gossypium armourianum Interspecific Hybrids
}

\author{
L. Mahalingam*, N. Premalatha, K. Senguttuvan, P. Latha and M. Kumar \\ ${ }^{1}$ Department of Cotton, Tamil Nadu Agricultural University, Coimbatore, India \\ *Corresponding author
}

\section{A B S T R A C T}

\section{Keywords}

Interspecific Hybridization, Wild Gossypium species, Triploid, Insect resistance

\section{Article Info}

Accepted:

25 November 2020 Available Online:

10 December 2020
Interspecific triploid hybrid was developed between tetraploid cultivated species Gossypium hirsutum genotypes MCU 5 and TCH 1819and diploid wild species Gossypium amourianum. The $\mathrm{F}_{1}$ hybridity was confirmed through morphological and cytological studies. The ploidy level of interspecific $F_{1}$ hybrids was triploid and male sterile. The maternal parents MCU 5 and TCH 1819 have exhibited erect growth habit, green stem, hairy stem and leaves, palmate, thick and prominent leaf veins, cream petals and embedded stigma. Both the hisutum genotypes MCU5 and TCH 1819 were showed similar expression in all morphological features except anther colour in which the MCU 5 showed dense yellow colour anther while dense creamy anther was observed in TCH 1819. The paternal parent diplpod wild species Gossypium armourianum had spreading growth habit, reddish green stem, cordate leaves, thin leaf veins, yellow petals, medium dense yellow anthers and protruded stigma. The growth habit, petal colour, leaf shape and size of interspecific $F_{1}$ hybrids were intermediate. Plant stem colour and hairiness, leaf pubescence, anther colour and stigma protrusion of Gossypium armourianum were observed to be dominant and the hybrid fully resembled Gossypium armourianum for these characters. Petal spot was observed in Gossypium armourianum and in $\mathrm{F}_{1}$ hybrids while petal spot was not present in MCU 5 and TCH 1819. Variable expression of petal spot, anther colour and filament colour was observed in the $\mathrm{F}_{1}$ hybrids. Gossypium hirsutum genotypes MCU 5 and TCH 1819 had 52 chromosomes, Gossypium armourianum had 26 chromosomes and 39 chromosomes was observed in the interspecific $\mathrm{F}_{1}$ hybrids of MCU x Gossypium armourianum and TCH 1819 x Gossypium armourianum through mitotic chromosomal study. Significant differences were observed between pollen

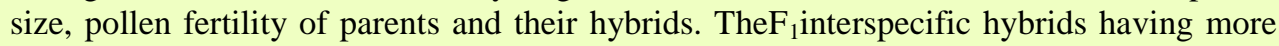
than 97 percent of sterile pollen grains. This $\mathrm{F}_{1}$ may be utilized as a pre breeding genetic resource for transfer of cotton jassid resistance to American cotton in breeding

\section{Introduction}

The genetic diversity of genus Gossypium spp is exclusively wide with diverse geographical and ecological niches (Fryxell, 1992).The genus Gossypium belongs to the family Malvaceae and contains more than 45 diploid species and five well documented allotetraploid species. Species of this genus are grouped into nine genome groups and 
designated as AD,A, B, C. D, E, F,G and K based on the similarities in chromosome size, structure and success of chromosomal pairing(Wendel,1989; Percy and Wendel,1999). Based on the chromosomal uniformity the diploid D genome species of the New World cotton include 26 chromosomes. Some hybrids within the genome are fertile and the chromosomere combination during meiosis. However, hybrids across genomes are generally infertile and have a few bivalents at meiosis as a result progeny plant survival from the interspecific crosses is sometime low. The allotetraploid cotton Gossypium hirsutum $\left(\mathrm{AD}_{1}\right)$ and Gossypium barbadense $\left(\mathrm{AD}_{2}\right)$ of the New World cotton dominate natural fibre production. Wild Gossypium species represent a significant genetic repository for potential exploitation by cotton breeders who have long recognized the beneficial effect of exotic genes (Heitholt and Manney, 2010).

The introduction of alien genetic variation into upland cotton from the chromosome of the wild species is a valuable and proven technique for cotton improvement. The introduction of alien genetic variation into upland cotton from the chromosome of the wild species is a valuable and proven technique for cotton improvement. The most successful examples of the use of wild species during the history of cotton breeding include Gossypium harknessii as a source of cytoplasmic male sterility (Meyer, 1975) and Gossypium thurberi as a source of fibre quality (Culp and Harrell, 1973; Culp et al., 1979). More recently, the other important traits such as nematode resistance and low gossypol plant traits were successfully introduced from diploid species into upland cotton using various strategies (Sacks and Robinson, 2009; Benbouza et al., 2010). The most of the genetic variation available in wild Gossypium species has to be exploited.

\section{Materials and Methods}

The crossing block comprises of two hirsutum genotypes viz., MCU 5 and TCH 1819raised during summer 2019 season. The male parent Gossypium armourianum is maintained at Cotton wild species garden. Crosses were effected by using Doak's method of hand emasculation and pollination. The $\mathrm{F}_{1}$ hybrids along with their parents were evaluated during winter 2019. The male parent Gossypium armourianum are being maintained in cotton wild species garden. The observations were recorded both in $\mathrm{F}_{1}$ hybrids and parents for various morphological and cytological studies (Plate 1).

Eighteen morphological characters viz., growth habit, stem colour, stem pubescence, petiole colour, leaf shape, leaf colour, leaf incision, leaf veins, leaf texture, leaf hairiness, bract size, corolla colour, petal size, petal spot, anther colour, anther density, filament colour and position of stigma were observed on both the parents and the $F_{1}$ hybrids in order to confirm the hybridity status of the $\mathrm{F}_{1}$ hybrids. Biometrical traits viz., number of bracterial teeth, bracterial length, bracterial breadth, petiole length, leaf length, leaf breadth, leaf area, pedicel length, petal length, petal breadth, pollen size diameter, pollen fertility (\%), length of pistil and gossypol gland density were observed on both the parents and $F_{1}$ hybrids.

Fourth fully matured and expanded leaves from the top of the plant were taken and their maximum length and breadth was recorded. Leaf area was measured from 5 fully expanded matured leaves of both parents and $\mathrm{F}_{1}$ hybrids using leaf area meter and averaged. Flowers were collected in morning on the day of anthesis between 10.00 am to 11.00 am for pollen fertility study. Pollen fertility was recorded by dusting pollen grains in $1 \%$ Potassium Iodide solution and viewed under a 
compound microscope. The large, darkly stained and circular pollen grains only considered as fertile. In both parents and $F_{1}$ hybrids four microscopic fields were taken to find out the pollen fertility percentage and averaged.

The mitotic metaphase chromosome study was carried out by using root tips to confirm the ploidy level of $F_{1}$ hybrids and their parents. Seeds of parents and their $F_{1}$ was soaked for overnight and germinated in the germination paper. The roots were collected with 2-3 cm length in quick succession between 9.00 am to 10.00 am on bright sunny days and pre-treated in paradichloro benzene to accumulate metaphase cells. After 2 hours, the pre- treated root tips washed thorouhgly in running tap water and fixed in the ethanol: glacial acetic acid (3:1) fixative. After keeping the fixed material under low temperature $\left(4^{\circ} \mathrm{C}\right)$ for a minimum period of four hours, the roots were thoroughly washed in the distilled water and stored in $70 \%$ ethanol. The roots were hydrolysed at $60^{\circ} \mathrm{C}$ for 5 minutes and washed thoroughly. Then the root tips are treated in a $0.25 \%$ pectinase solution for 15 minutes in dark and put it in basic fuchsin stain for 30 minutes in dark. The darkly stained extreme tip portion of the roots were excised out and macerated in a drop of $1 \%$ acetocarmine. After maceration the slide covered with cover slip and heated gently over a sprit lamp. The excess stain was removed by giving gentle press with thumb between two layers of filter paper. The slide was temporarily sealed using wax and observed under the Olympus system microscope @1000X magnification. The chromosomes were counted from the metaphase cells and recorded pictorially.

\section{Results and Discussion}

Morphological features of parents MCU 5, TCH 1819, Gossypium armourianum and their corresponding $\mathrm{F}_{1}$ hybrids of MCU $5 \mathrm{x}$ Gossypium armourianum and TCH $1819 \mathrm{x}$ Gossypium armourianum were compared and presented in Table 1 and 2. Interspecific $F_{1}$ hybrids exhibited either dominance or intermediate expression for various morphological traits. Growth habit, leaf shape, leaf size, leaf incision and petal colour of interspecific hybrid were found to be intermediate. The maternal parents MCU 5 and TCH 1819 had deep leaf incision and Gossypium armourianum had no leaf incision whereas, the $F_{1}$ hybrids had shallow leaf incision. Leaf shape of MCU 5 and TCH 1819 was palmate with 3-4 lobes, whereas Gossypium armourianum had cordate leaves. In case of $F_{1}$ hybrid, leaves were palmate with 3-4 lobes and reduced in size as compared to Gossypium hirsutum leaves(Plate 2). Pushpam and Raveendran (2006) and Kaur et al., (2016) have reported intermediate leaf shape and size in hybrids between Gossypium hirsutum and Gossypium armourianum. Similar intermediate expression of plant growth habit, leaf size and petal colour have reported in other interspecific hybrids such as between Gossypium davidsoniix Gossypium anomalum, Gossypium arboreumx Gossypium thurberi, Gossypium hirsutumx Gossypium arboreum (Ahmad et al., 2011; Tahir and Noor, 2011) and Gossypium herbaceumx Gossypium australe( Liu et al., 2015). Plant stem colouration and hairiness, leaf pubescence, position of stigma, anther colour of Gossypium armourianum were found to be dominant as hybrid fully resembled the male parent for these characters. Average pollen fertility of 92.55, 93.83, 97.22and $0.30-1.09$ $\%$ in MCU 5, TCH 1819, Gossypium armourianum and $\mathrm{F}_{1}$ hybrids respectively (Tabl 3 and 4) .Pollen fertility between parents and hybrids showed significant difference. Pushpum and Raveendran (2006) reported $9.04 \%$ average pollen fertility in Gossypium hirsutumx Gossypium armourianum hybrid and $9.67 \%$ in 
Gossypium hirsutumx Gossypium raimondii hybrids. $2.19 \%$ average pollen fertility was recorded by Kaur et al., (2016) in Gossypium hirsutumx Gossypium armourianum hybrids. The average pollen size of MCU 5, TCH 1819 , Gossypium armourianum and $\mathrm{F}_{1}$ hybrid was determined to be $39.51,39.93,34.34$ and $21.37-25.29 \mu$ respectively (100X). Pollen size of $F_{1}$ hybrids shows more variation when compared to parents. Significant differences were observed between the pollen sizes of the parents as well as between the parents and their hybrids. Generally petal spot was not observed in Gossypium hirsutum while it was found in Gossypium armourianum. The $\mathrm{F}_{1}$ hybrids of MCU 5 x Gossypium armourianum and TCH 1819 x Gossypium armourianum exhibited variation for petal spot size and intensity in different flowers of the same plant. It ranged from complete absence to dark pink colour with full size as that of male parent (Plate 1 and Plate 2). Similar results were obtained by Kaur et al., (2016) in Gossypium hirsutum cv., 1861 x Gossypium armourianum. However, complete dominance of petal spot in intra hirsutum crosses involving wild type $\mathrm{x}$ mutant strains were reported by Ahuja and Dhayal (2007). Tahir and Noor (2011) and Ahmad et al. (2011) have reported reduction in the colour intensity of petal spot in $\mathrm{F}_{1}$ hybrids in case of Gossypium hirsutumx Gossypium arboreum cross. Intermediate expression of filament colour was observed in the $F_{1}$ hybrid. Similar results were reported by Kaur et al., (2016) in the $\mathrm{F}_{1}$ hybrids of Gossypium hirsutum cv. F 1861 x Gossypium armourianum.

Table.1 Morphological traits of parents and $\mathrm{F}_{1}$ hybrid of MCU 5 x G. armourianum

\begin{tabular}{|r|l|l|l|l|}
\hline S.No & \multicolumn{1}{|c|}{ Characters } & \multicolumn{1}{|c|}{ MCU 5 } & $\begin{array}{l}\text { MCU 5 } \\
\text { G.armourianum }\end{array}$ & \multicolumn{1}{|c|}{ G.armourianum } \\
\hline $\mathbf{1}$ & Growth habit & Annual, erect & Perennial,semi spreading & $\begin{array}{l}\text { Perennial, semi } \\
\text { spreading }\end{array}$ \\
\hline $\mathbf{2}$ & Stem colour & Dark green with brown & Brownish purple green & Brownish purple \\
\hline $\mathbf{3}$ & Stem pubescence & Sparsely pubescent & Glabrous & Glabrous \\
\hline $\mathbf{4}$ & Petiole colour & Greenish brown & Brownish green & Brownish green \\
\hline $\mathbf{5}$ & Leaf shape & Palmate with 3-5 lobes & Palmate with slight lobes & Cordate \\
\hline $\mathbf{6}$ & Leaf colour & Green & Dark green & Green \\
\hline $\mathbf{7}$ & Leaf incision & Shallow to slighty deep & Shallow & Shallow \\
\hline $\mathbf{8}$ & Leaf veins & Thick and prominent & Thick and prominent & Thin \\
\hline $\mathbf{9}$ & Leaf texture & Medium smooth & Smooth & Smooth \\
\hline $\mathbf{1 0}$ & Leaf hairiness & Sparsely hairy & Glabrous & Glabrous \\
\hline $\mathbf{1 1}$ & Bract size & Medium & Small & Caducous bract \\
\hline $\mathbf{1 2}$ & Corolla colour & Creamy white & Light yellow & Yellow \\
\hline $\mathbf{1 3}$ & Petal size & Medium & Medium & Medium \\
\hline $\mathbf{1 4}$ & Petal spot & Absent & Present & Present \\
\hline $\mathbf{1 5}$ & Anther colour & Yellow & Yellow with red spot & Yellow with red spot \\
\hline $\mathbf{1 6}$ & Anther density & Dense & Medium & Medium \\
\hline $\mathbf{1 7}$ & Filament colour & White to creamy white & White to creamy white & White to creamy white \\
\hline $\mathbf{1 8}$ & Position of stigma & Embedded & Protruded & Protruded \\
\hline & & & & \\
\hline
\end{tabular}


Table.2 Morphological traits of parents and $\mathrm{F}_{1}$ hybrid of TCH 1819 x G. armourianum

\begin{tabular}{|r|l|l|l|l|}
\hline S.No. & \multicolumn{1}{|c|}{ Characters } & \multicolumn{1}{|c|}{ TCH 1819 } & $\begin{array}{l}\text { TCH 1819 } \\
\text { G.armourianum }\end{array}$ & \multicolumn{1}{|c|}{ G.armourianum } \\
\hline $\mathbf{1}$ & Growth habit & Annual shrub & $\begin{array}{l}\text { Perennial, semi } \\
\text { spreading }\end{array}$ & Perennial, semi spreading \\
\hline $\mathbf{2}$ & Stem colour & Dark green & Brownish purple green & Brownish purple \\
\hline $\mathbf{3}$ & Stem pubescence & Sparsely pubescent & Glabrous & Glabrous \\
\hline $\mathbf{4}$ & Petiole colour & Green & Greenish purple & Brownish green \\
\hline $\mathbf{5}$ & Leaf shape & Palmate with 2-4 lobes & $\begin{array}{l}\text { Palmate with slight } \\
\text { lobes }\end{array}$ & cordate \\
\hline $\mathbf{6}$ & Leaf colour & Light green & Dark green & Dark green \\
\hline $\mathbf{7}$ & Leaf incision & $\begin{array}{l}\text { Shallow to slightly } \\
\text { deep }\end{array}$ & Shallow & Shallow \\
\hline $\mathbf{8}$ & Leaf veins & Thick and prominent & Thick and prominent & Thin \\
\hline $\mathbf{9}$ & Leaf texture & Medium smooth & Thin smooth & Smooth \\
\hline $\mathbf{1 0}$ & Leaf hairiness & Sparsely hairy & Glabrous & Glabrous \\
\hline $\mathbf{1 1}$ & Bract size & Medium & Small & Caducous bract \\
\hline $\mathbf{1 2}$ & Corolla colour & Creamy white & Light yellow & Yellow \\
\hline $\mathbf{1 3}$ & Petal size & Medium & Medium & Medium \\
\hline $\mathbf{1 4}$ & Petal spot & Absent & Present & Present \\
\hline $\mathbf{1 5}$ & Anther colour & Creamy white & Yellow with red spot & Yellow with red spot \\
\hline $\mathbf{1 6}$ & Anther density & Dense & Medium & Medium \\
\hline $\mathbf{1 7}$ & Filament colour & White to creamy white & White to creamy white & White to creamy white \\
\hline $\mathbf{1 8}$ & Position of stigma & Embedded & Protruded & Protruded \\
\hline & & & & \\
\hline
\end{tabular}

Table.3 Biometrical traits of parents and $\mathrm{F}_{1}$ hybrid of MCU 5 x G. armourianum

\begin{tabular}{|c|c|c|c|c|}
\hline S.No & Characters & MCU 5 & $\begin{array}{c}\text { MCU } 5 \text { x } \\
\text { G.armourianum }\end{array}$ & G.armourianum \\
\hline 1 & Number of bracterial teeth & $9.66 * *$ & $6.58 * *$ & - \\
\hline 2 & Bracterial length $(\mathrm{cm})$ & $3.78 * *$ & $2.43 * *$ & - \\
\hline 3 & Bracterial breadth $(\mathrm{cm})$ & $2.77 * *$ & $1.76 * *$ & - \\
\hline 4 & Petiole length $(\mathrm{cm})$ & $11.75 * *$ & $5.44 * *$ & $1.28 * *$ \\
\hline 5 & Leaf length $(\mathrm{cm})$ & $13.91 * *$ & $7.42 * *$ & $3.56 * *$ \\
\hline 6 & Leaf breadth $(\mathrm{cm})$ & $13.25 * *$ & $7.62 * *$ & $3.45 * *$ \\
\hline 7 & Leaf $\operatorname{area}\left(\mathrm{cm}^{2}\right)$ & $154.85 * *$ & $36.62 * *$ & $7.09 * *$ \\
\hline 8 & Pedicel length $(\mathrm{cm})$ & $1.27^{\mathrm{a}}$ & $2,22^{b}$ & $1.40^{\mathrm{a}}$ \\
\hline 9 & Petal length $(\mathrm{cm})$ & $3.87 * *$ & $4.31 * *$ & $4.97 * *$ \\
\hline 10 & Petal breadth $(\mathrm{cm})$ & $3.50 * *$ & $4.29 * *$ & $4.98 * *$ \\
\hline 11 & Pollen size diameter $(\mu)$ & $39.51 * *$ & $25.29 * *$ & $34.34 * *$ \\
\hline 12 & Pollen fertility (\%) & $92.55 * *$ & $1.09 * *$ & $97.22 * *$ \\
\hline 13 & Length of pistil(cm) & $2.27^{\mathrm{a}}$ & $3.07^{\mathrm{b}}$ & $3.50^{\mathrm{b}}$ \\
\hline 14 & Gossypol gland density & $11.00^{\mathrm{a}}$ & $8.50^{b}$ & $11.25^{\mathrm{a}}$ \\
\hline
\end{tabular}


Table.4 Biometrical traits of parents and $\mathrm{F}_{1}$ hybrid of TCH 1819 x G.armourianum

\begin{tabular}{|l|l|c|c|c|}
\hline S.No & Characters & TCH 1819 & $\begin{array}{c}\text { TCH 1819 x } \\
\text { G.armourianum }\end{array}$ & G.armourianum \\
\hline $\mathbf{1}$ & $\begin{array}{l}\text { Number of bracterial } \\
\text { teeth }\end{array}$ & $10.00^{* *}$ & $7.16^{* *}$ & - \\
\hline $\mathbf{2}$ & Bracterial length(cm) & $4.27^{* *}$ & $2.42^{* *}$ & - \\
\hline $\mathbf{3}$ & Bracterial breadth(cm) & 1.95 & 1.73 & - \\
\hline $\mathbf{4}$ & Petiole length(cm) & $12.21^{* *}$ & $5.80^{* *}$ & $1.28^{* *}$ \\
\hline $\mathbf{5}$ & Leaf length(cm) & $14.97^{* *}$ & $8.91^{* *}$ & $3.56^{* *}$ \\
\hline $\mathbf{6}$ & Leaf breadth(cm) & $14,80^{* *}$ & $8.57^{* *}$ & $3.45^{* *}$ \\
\hline $\mathbf{7}$ & Leaf area(cm $\left.{ }^{2}\right)$ & $157.73^{* *}$ & $49.84^{* *}$ & $7.09^{* *}$ \\
\hline $\mathbf{8}$ & Pedicel length(cm) & $1.57^{\mathrm{a}}$ & $3.07^{\mathrm{b}}$ & $1.53^{\mathrm{a}}$ \\
\hline $\mathbf{9}$ & Petal length(cm) & $4.62^{* *}$ & $4.49^{* *}$ & $4.97^{* *}$ \\
\hline $\mathbf{1 0}$ & Petal breadth(cm) & $3.91^{\mathrm{a}}$ & $4.62^{\mathrm{b}}$ & $4.98^{\mathrm{b}}$ \\
\hline $\mathbf{1 1}$ & Pollen size diameter( $(\mu)$ & $39.93^{* *}$ & $21.37^{* *}$ & $34.34^{* *}$ \\
\hline $\mathbf{1 2}$ & Pollen fertility(\%) & $93.83^{* *}$ & $0.30^{* *}$ & $97.22^{* *}$ \\
\hline $\mathbf{1 3}$ & Length of pistil(cm) & $2.20^{* *}$ & $2.82^{* *}$ & $3.50^{* *}$ \\
\hline $\mathbf{1 4}$ & Gossypol gland density & $6.50^{* *}$ & $9.00^{* *}$ & $11.25^{* *}$ \\
\hline
\end{tabular}

Plate.1 Parents used for crossing

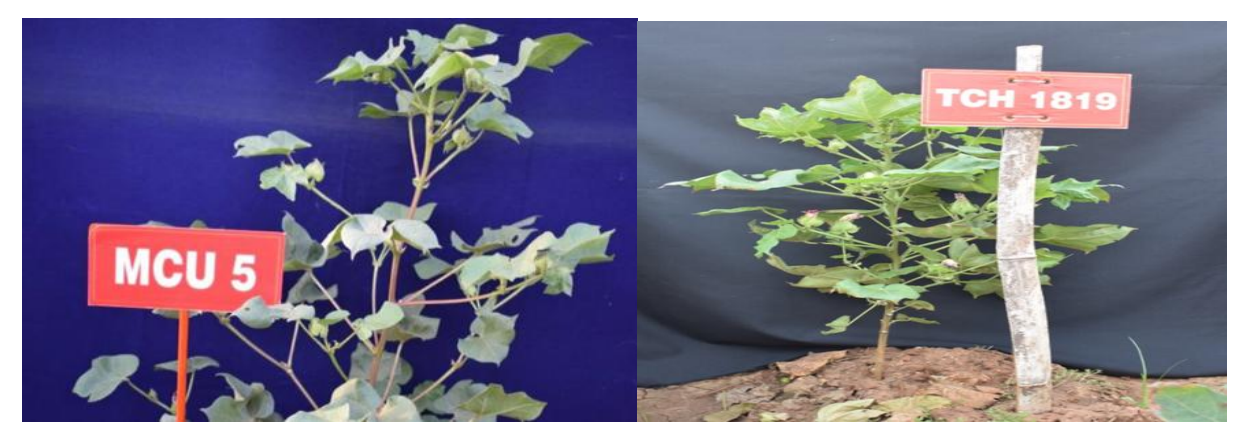

MCU 5

TCH 1819

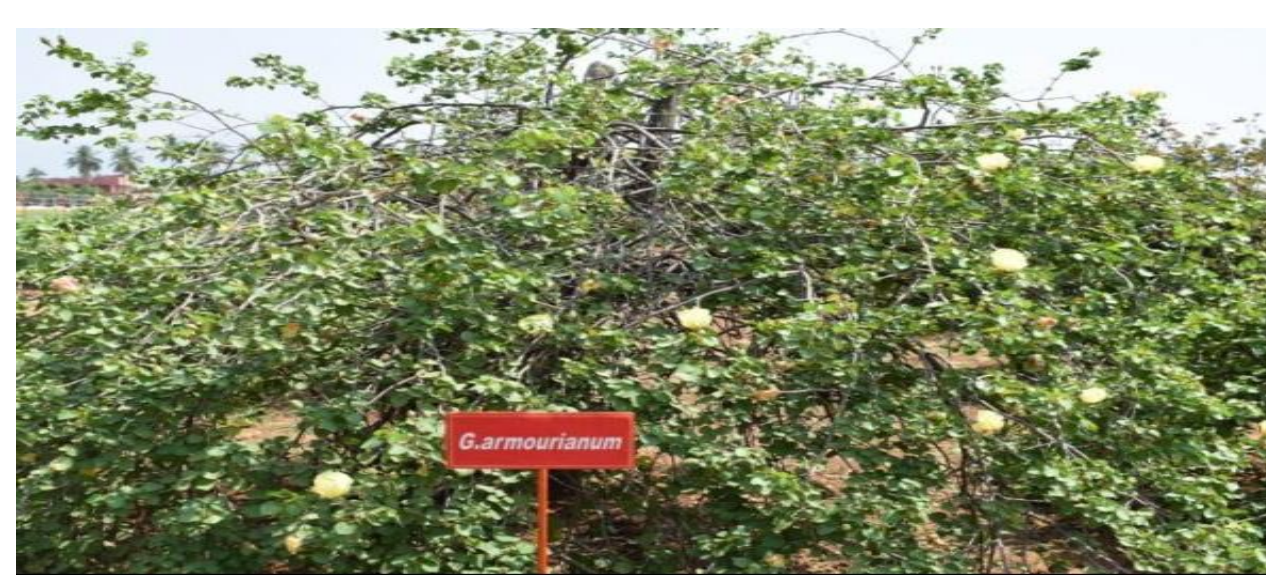


Plate.2 Morphological features of parents and hybrids
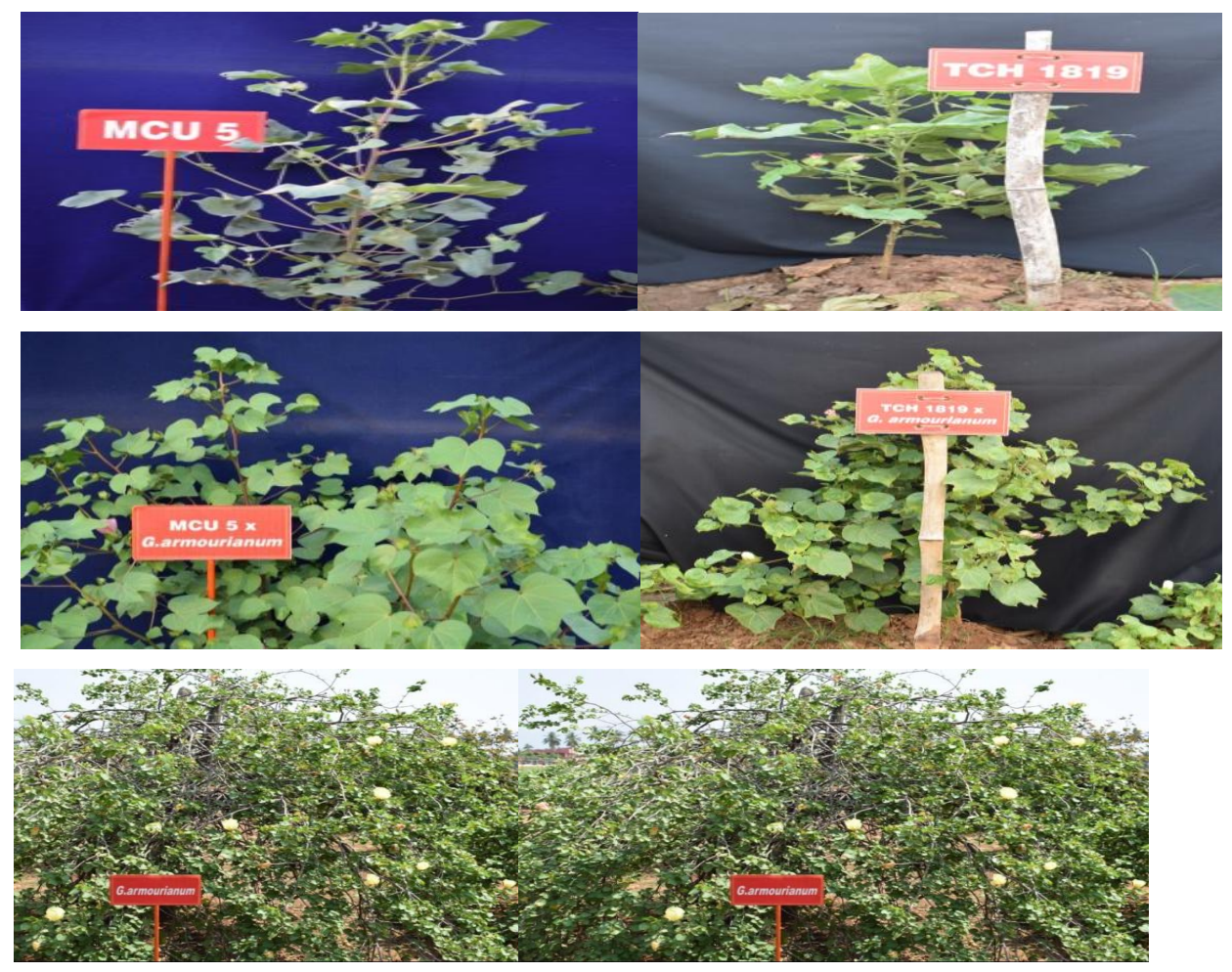

Plate.3 Floral morphology of parents and hybrids

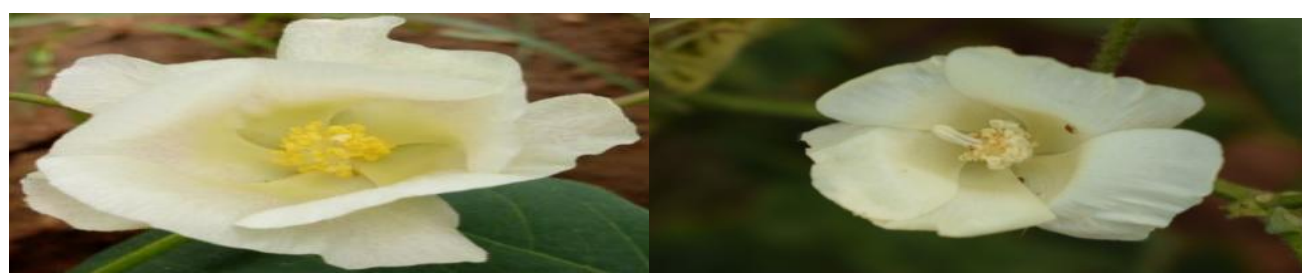

MCU STCH 1819

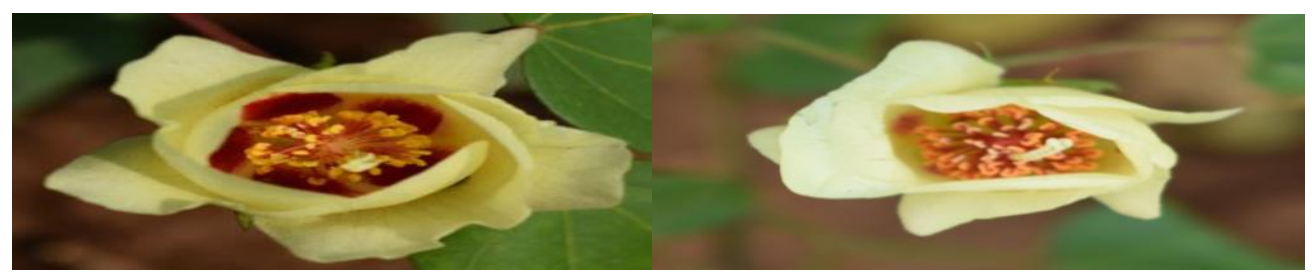

MCU 5 X G.armourianumTCH $1819 \times$ G.armourianum

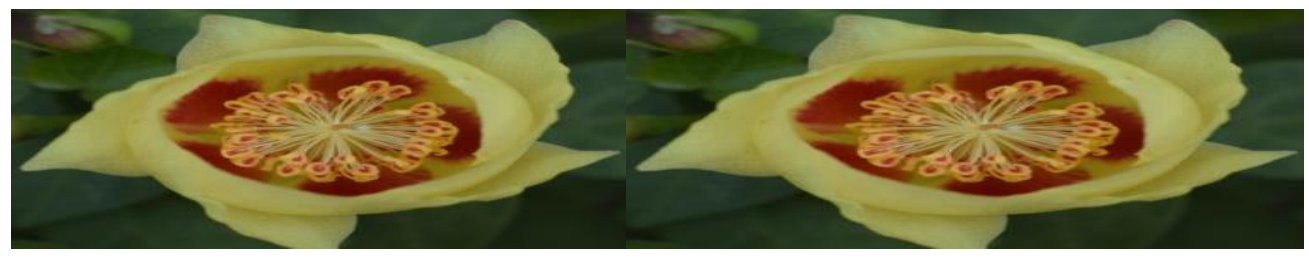

G.armourianum G.armourianum 
Plate.4 Petal morphology of parents and hybrids
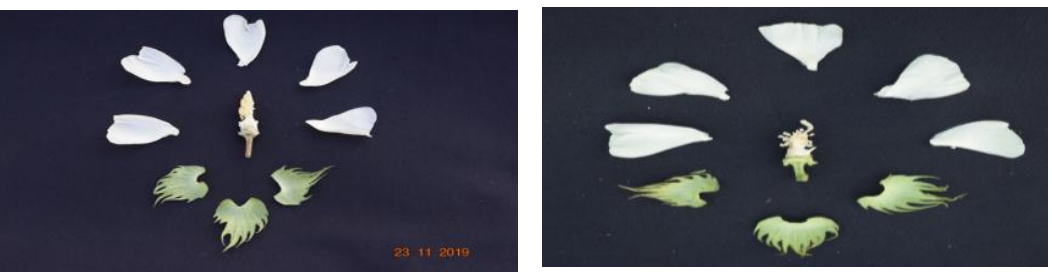

MCU 5TCH 1819

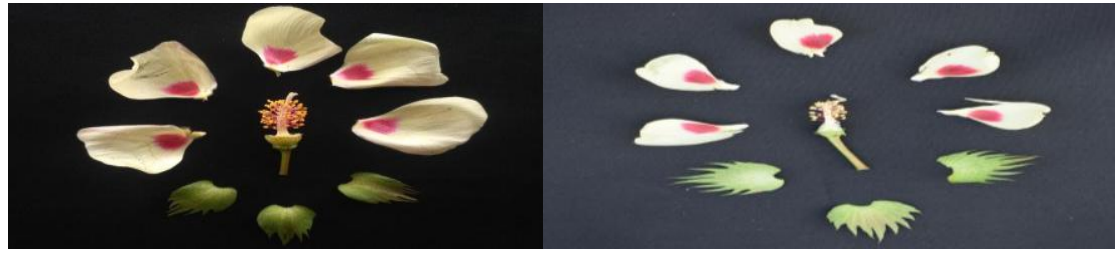

MCU 5 x G.armourianum T CH 1819 x G.armourianum

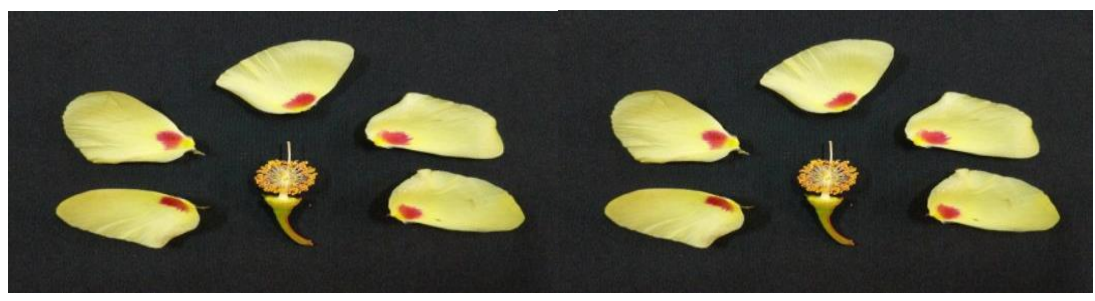

G.armourianumG.armourianum

Plate.5 Pollen fertility of parents and hybrids

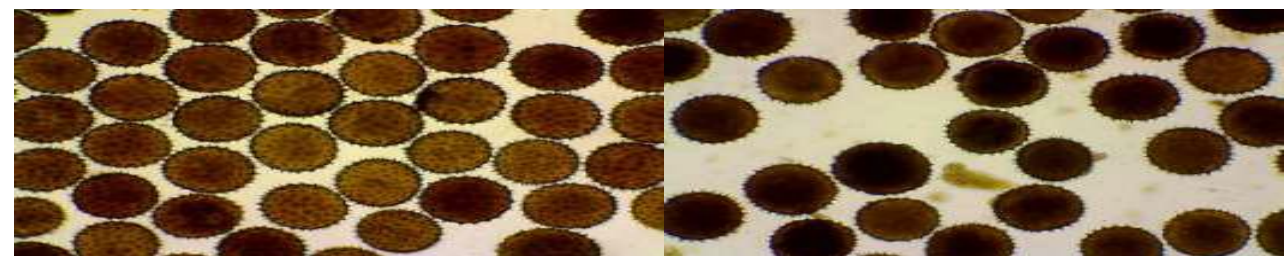

MCU 5

TCH 1819
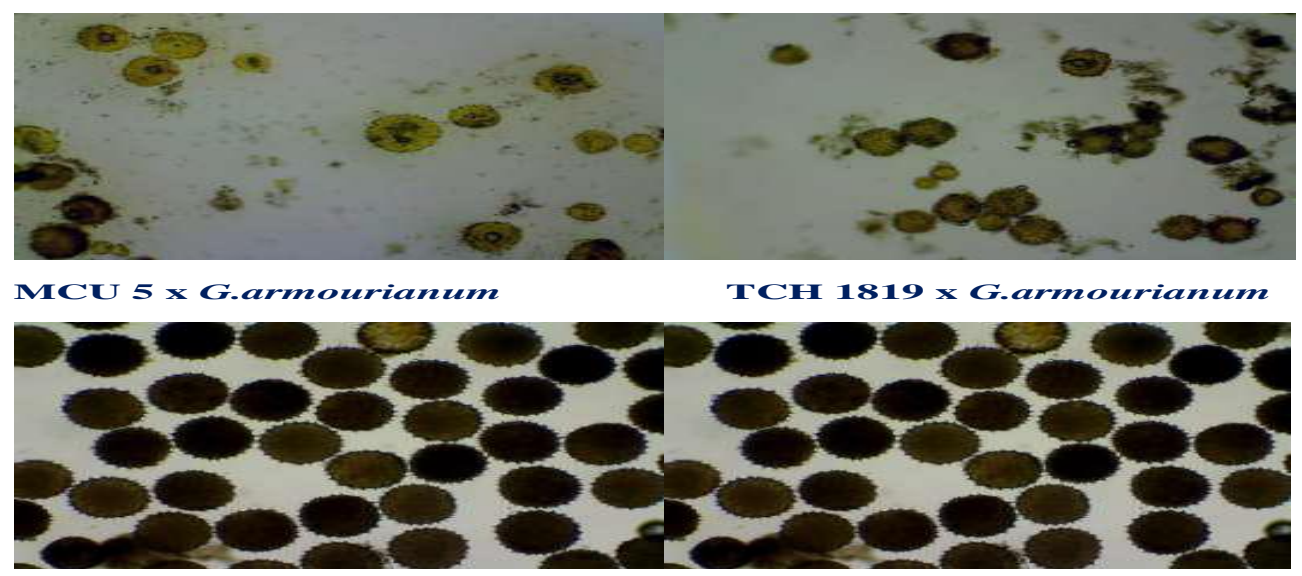

G.armourianum G.armourianum 
Plate.6 Cytological study in parents and hybrids

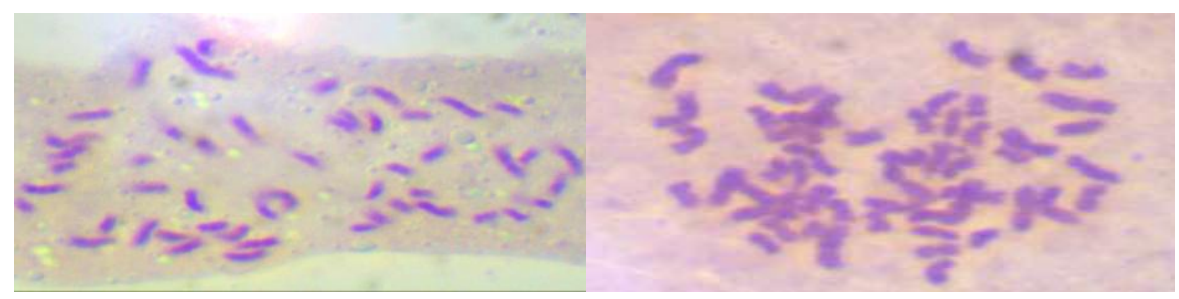

$\operatorname{MCU} 5$

TCH 1819

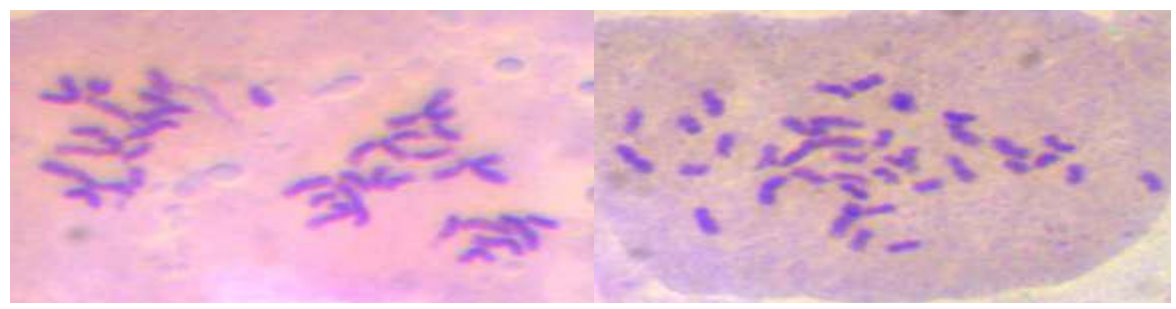

MCU 5 x G.armourianum

TCH 1819 x G.armourianum

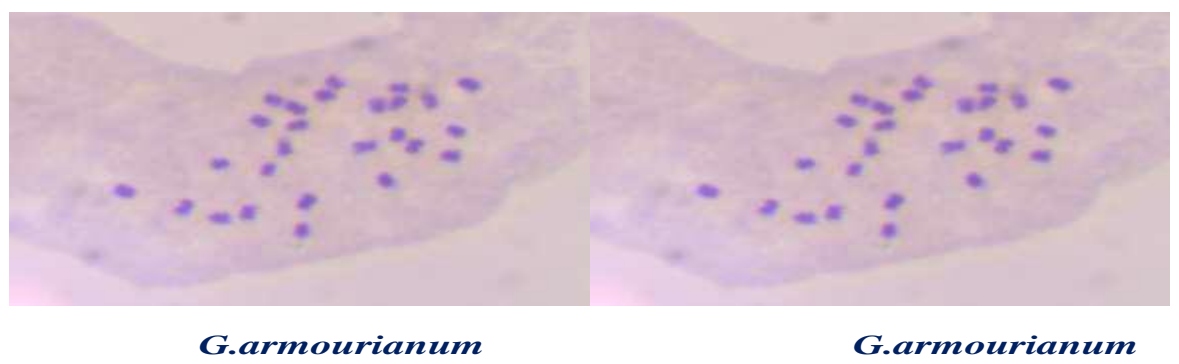

Filament colour of boththe parents were colourless. But in case of $\mathrm{F}_{1}$ hybrid, filament was either coloured or colourless in different flower bud and, even within same plant both coloured and colourless filaments were also observed (Plate 3). Kaur et al., (2016) also observed similar results in Gossypium hirsutum $c v$. F 1861 x Gossypium armourianum. The portion that connects the filament and the anther was coloured in male parent and colourless in female parent, whereas both coloured and colourless connectives were observed in the same flower and different flowers of the same plant in the $\mathrm{F}_{1}$ hybrids. Similar variation was observed by Kaur et al., (2016) in the $\mathrm{F}_{1}$ hybrid of Gossypium hirsutum cv. F 1861 x Gossypium armourianum.Kauret al., (2016) viewed that the variations was observed in morphological traits of the $\mathrm{F}_{1}$ hybrid between Gossypium hirsutum cv. F 1861 and Gossypium armourianum may be due to "Epigenetics". Rapp and Wendel (2005) considered epigenetics as the alteration of phenotypes, without change in their coding sequence of the gene or the upstream promoter region. In beginning allopolyploids are reported to be associated with variation and instability in phenotypes that cannot be accounted for by conventional Mendelian transmission genetics or chromosomal aberrations (Comai, 2000). Biometrical characters of parents and $F_{1}$ hybrids are compared and presented in Table 3 and 4.Leaf area and petiole length of interspecific $F_{1}$ hybrid were found to be intermediate. MCU 5, TCH 1819 and Gossypium armourianum had the leaf area of $154.85 \mathrm{~cm} 2, \quad 157.73 \mathrm{~cm}^{2}$ and $7.09 \mathrm{~cm}^{2}$ respectively, whereas the leaf area of $\mathrm{F}_{1}$ hybrids MCU 5 x Gossypium armourianum 
and TCH 1819 x Gossypium armourianum were $36.62 \mathrm{~cm}^{2}$ and $49.84 \mathrm{~cm}^{2}$ respectively which are intermediate between both the parents. Petiole length of MCU 5 and Gossypium armourianum was $11.75 \mathrm{~cm}$ and $1.28 \mathrm{~cm}$ respectively, whereas the $F_{1}$ hybrid exhibits the intermediate length of $5.44 \mathrm{~cm}$. Petiole length of TCH 1819 and Gossypium hirsutum was $12.21 \mathrm{~cm}$ and $1.28 \mathrm{~cm}$ respectively, whereas the $F_{1}$ exhibits the intermediate length of $5.80 \mathrm{~cm}$.Mitotic metaphase counts revealed that the presence of 52 chomosomes in Gossypium hirsutum genotypes MCU 5 and TCH 1819, 26 chromosomes in Gossypium armourianum, 39 chromosomes in corresponding $\mathrm{F}_{1}$ hybrids and confirmed the triploid status of the $\mathrm{F}_{1}$ hybrids developed from cross between MCU $5 \mathrm{x}$ Gossypium armourianum and TCH $1819 \mathrm{x}$ Gossypium armourianum (Plate 6). These $\mathrm{F}_{1}$ hybrids are important genetic resources for cotton breeders to develop pest and disease resistant cultivars. These materials can be used as bridges for the transfer of pest and disease resistant genes from the wild species to cultivated varieties.

\section{References}

AhmadS., Mahmood K., Hanif M., Nazeer W., Malik W.,Qayyum X. and N. IslamIslam N. 2011.Introgression of cotton leaf curl virus-resistant genes from W Asiatic cotton (Gossypium arboreum) into upland cotton (G.hirsutum). Genet. Mol. Res., 10(4): 2404-2414.

Ahuja S. L, and Dhayal L.S.2007. Comparative characteristics and gene action in three petal spotted mutants of Gossypium hirsutum. J.Genet., 86(1) : 81-84.

Benbouza H., Lacape J.M.,Jacquemin J.M.,Courtois B.,Diouf F.B.H.Sarr D., Konan N.,Baudoin J.P. and Mergeai G.2010.Introgression of the low- gossypol seed \&high-gossypol plant trait in upland cotton: analysis of [(Gossypium hirsutum $\times$ G.raimondii $) 2$ $\times$ G. sturtianum] trispecific hybrid and selected derivatives using mapped SSRs. Mol. Breed.,25: 273-286

Comai L.2000. Genetic and epigenetic interactions in allopolyploid plants.Plant Gene Silencing, 267-279.

CulpT.W. and Harrell T.C..1973. Breeding methods for improving yield and fiber quality of upland cotton (Gossypium hirsutumL.), Crop Sci., 13: 686-689

CulpT.W., Harrell T.C. and Kerr T.1979. Some genetic implications in the transfer of high fiber strength genes to upland cotton, Crop Sci., 19: 481-484

Doak C.C.1934. A new technique in cotton hybridization suggested changes in existing methods of emasculating and bagging cotton flowers. J.Hered.,25: 201-204

FryxellP.A.1992. A revised taxonomic interpretation of Gossypium L. (Malvaceae), Rheedea 108-165

Heitholt J.and Mauney R.2010. Physiology of Cotton, Springer, Netherland pp 1-18

Kaur H., Pathak D. and Rathore P. 2016.Development and characterization of an interspecific Gossypium hirsutum x Gossypium armourianum hybrid.Appl. Biol. Res., 18(2): 146-154.

Liu Q., Chen Y., Wang Y., Chen J., Zhang T. and ZhouB. 2015. A New Synthetic Allotetraploid (A1A1G2G2) between Gossypium herbaceum and $G$. australe: bridging for simultaneously transferring favorable genes from these two diploid species into upland cotton. PLOS one, 10(4).

Manickam S. and Prakash A.H.2014. Interspecific hybridization between Gossypium hirsutum and $G$ armourianum: Morphological and Molecular Characterization of 
Hybrids. Cotton Res. J., 6(1): 7-12

Pushpam R.and Raveendran T.S. 2006.Production of interspecific hybrids between Gossypium hirsutum and Jassid resistant wild species G.raimondii and G.armourianum.Cytologia, $\quad$ 71(4): 407-418.

Rapp R. A. and Wendel J.F.2005.Epigenetics and plant evolution. NewPhytol, 168(1): 81-91.

SacksE.J. and Robinson A,F. 2009. Introgression of resistance to reniform nematode Rotylenchulusreniformis) into upland cotton (Gossypium hirsutum) from Gossypium arboreum . hirsutum/Gossypium aridum bridging line, Field Crops Res.,112: 1-6

SaravananN. A., Ram S.G., Thiruvengadam V., Ravikesavan R. and Raveendran T.S.2007.Production and Fertility
Restoration of an Interspecific Hybrid between Gossypium hirsutum L. andG. raimondii. Cytologia, 72(2): 195-203.

Shim J., Mangat P.K. and Angeles-Shim R.P.2018.Natural variation in wild Gossypium species as a tool to broaden the genetic base of cultivated cotton. $J$. Plant Sci. Curr. Res., 2 :5.

Tahir M. S. and Noor U. I.K.2011. Development of an interspecific hybrid (Triploid) by crossing Gossypium hirsutum and G.arboreum. Cytologia, 76(2): 193-199.

WendeJ.F.1989. New World tetraploid cottons contain old world cytoplasm. Proc. Natl. Acad. Sci. U.S.A. 86: 4132-4136

Zhang J.and Stewart J.M.2000. Economical and rapid method for extracting cotton genomic DNA. J.Cotton Sci., 4(3): 193-201.

\section{How to cite this article:}

Mahalingam, L., N. Premalatha, K. Senguttuvan, P. Latha and Kumar, M. 2020. Development and Characterization of Gossypium hirsutum and Gossypium armourianum Interspecific Hybrids. Int.J.Curr.Microbiol.App.Sci. 9(12): 3211-3221. doi: https://doi.org/10.20546/ijcmas.2020.912.382 